\section{Työelämän vinoumista uudistumiseen}

Minna Mattila-Aalto (2020). Työelämän uudistumisen esteet. Työyhteisön sivistys ja vastuu. Basam Books. 159 sivua.

TYÖELÄMÄN UUDISTUMISEN $e S-$ teet on herättävä puheenvuoron työelämäsivistyksen puolesta. Minna Mattila-Aallolla on kokemusta työelämän kehittämisestä kolmelta vuosikymmeneltä. Hän tarkastelee nykymenoa vuorovaikutuksen sosiologin, tutkijan ja työelämän kehittään linssien takaa.

Kirjassa kuvataan työelämän vinoumia ja uudistumisen esteitä. Tarkastelua kannattelee sivistyksen ja työelämän välinen jännite. Alussa ne näyttävät olevan kuin eri planeetoilta, mutta teoksen edetessä sivistys valtaa tilaa työelämän raadollisuudelta - ja lopulta jopa raivaa uudistumisen esteitä.

Näkökulmana on yksilön kokemusmaailma, mikä on kirjoittajan taustasta käsin ymmärrettävää. Kerronta tulee "iholle", ja lukija vakuuttuu, että kirjoittaja on kaiken nähnyt ja kokenut.

Kirja koostuu kymmenistä esimerkeistä, joissa yksilö jää ikään kuin työelämän vangiksi tai "virran viemäksi". Yhteen työuraan kertyy 80000 työtuntia, kymmeniä tuhansia töihin lähtöjä ja työnteon toistosta syntyvää arjen maratonia, kuten Mattila-Aalto kuvaa. Hän kritisoi työelämän muuttunee entistä kiireisemmäksi ja kaoottisemmaksi. Samalla hän tuo esille mielenkiintoisen yksityiskohdan: vaikka olemme yksi maa- ilman onnellisimpia kansoja, yhä useampi uupuu työssään. Jotain pitäisi tehdä!

\section{TYÖYHTEISÖ ON}

VALTANÄYTTÄMÖ

Kirjan mielenkiintoisinta antia ovat kärjistetyt elävän elämän esimerkit, joilla Mattila-Aalto haluaa provosoida lukijaa ja tuoda esiin työpaikoilla toistuvia jaksamisen ongelmia. Sanomaansa hän tukee retorisilla keinoilla ja työelämän problematiikan yliyksinkertaistuksilla. Tehokeinojen toimivuus riippuu lukijasta: Radikaalit kärjistykset toki kiehtovat mielikuvitusta toisin kuin tasainen todellisuus. Jonkun taas voi olla vaikea tunnistaa kirjan osittain pessimististä sävyä työelämän vaatimuksista ja muutoksesta.

Joissakin kohdissa kirjoittaja vahvistaa viestiään vetoamalla "tutkimuksiin" tai "tutkijat ovat osoittaneet" -tyyppisiin lausahduksiin. Jäimme kaipaamaan suoraa viittausta lähteisiin. Lähteet on koottu kirjan loppuun, joten tarpeettoman retorisen keinon olisi voinut jättää käyttämättä. Paikoin kirjoittaja yksinkertaistaa asiansa ilman perusteluja: esimerkiksi väite, että "pelolla johtaminen on edelleen yksi suurista ongelmista työpaikoilla" kaipaisi tutkitun tiedon vahvistusta.
MINNA MATTILA-AALTO

TYÖELÄMÄN

UUDISTUMISEN

ESTEET

Työyhteisön

sivistys

ja vastuu

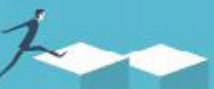

$>$

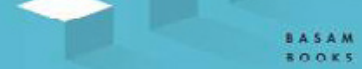

DASAM
BOOKS

Minna Mattila-Aalto kuvaa työelämän kyräilevän kulttuurin, jossa on mukana tunteiden negatiivinen kirjo: pelko, häpeä, alemmuus. Työyhteisöt ovat valtanäyttämöitä, joissa johdolla on valtaa, jota ei kuitenkaan käytetä hyvän työyhteisön rakentamiseen. Menestyksen tavoittelu luo sokeutta ja kapeakatseisuutta: "Ajamme sumuvalot päällä."

\section{SIVISTYS ON PROSESSI}

Kirjan sanoma on, että puhumattomuus ja vuorovaikutuksen puute ajavat meidät tekemään omia tulkintojamme työelämän todellisuudesta. Moni haaste voisi purkautua vuorovaikutusta vahvistamalla, mistä vastuu on erityisesti organisaation johdolla. MattilaAallon mukaan johtajat voivat tavoitella työn arjessa organisaation yhteistä hyvää, mutta keinot eivät aina vastaa tarkoitustaan.

”Ei riitä, että katsoo. Pitää myös nähdä", kirjassa todetaan. Tämä näkökulma puhutteli meitä. Kai- 
killa on toive tulla ymmärretyksi ja nähdyksi, myös työyhteisössä. Syvät keskustelut rakentuvat hitaasti ja vaativat keskittymistä.

Pelkoa ja vuorovaikutuksen puutetta työyhteisössä voivat aiheuttaa muutkin kuin johtajat ja esimiehet. Kunkin on hyvä miettiä, miten itse toimii työyhteisön jäsenenä. Kuinka herkästi tuo esiin tekemänsä virheet? Miten itse suhtautuu epäkohtien paljastajiin? "Itselleen totta puhuminen se vasta ballseja vaatiikiin., Mattila-Aalto sanoo. Juuri näin!

Kirjan tärkeintä antia ovat pohdinnat työelämän sivistyksestä ratkaisuna vinoumiin. Kirjoittaja toteaa viisaasti, että muuttuvassa työelämässä sivistys ei ole saavutettu tila vaan jatkuvaa ristiriitaa ja kamppailua siitä, minkälaista työyhteisön toimintaa ja yrityskulttuuria pidetään oikeana, järkevänä ja hyvänä.

\section{SIVISTYS ON TOIMINTAA}

Lopuksi kirjoittaja tuo sivistyksen ja työelämän samalle pla- neetalle. Hän määrittelee 'työelämäsivistyksen': työpaikoilla toimivat ihmiset asemastaan riippumatta kypsyvät ymmärtämään kuuluvansa työyhteisöön, joka velvoittaa heitä vastuulliseen ja moraaliseen toimintaan. Hän peräänkuuluttaa moraalia ja vastuullisuutta niin työyhteisön ja ihmiskunnan kuin maapallon hyvinvoinnin takia. Tätä pohdintaa olisimme toivoneet vielä lisää.

Mattila-Aalto toteaa, että työn sujumisen ja jaksamisen ongelmat on helppo peittää työhyvinvointipuheella, jolloin asioiden todellinen laita jää toteamatta. Hän kysyy, onko oikein jättää ihmiset ratkomaan ongelmia, joita yhdessä tuotamme. Onko sivistynyttä ohittaa yhteiset ongelmat, pitää niitä yksittäisten ihmisten jaksamisen, osaamisen tai ties minkä ongelmina? Vastaus on yksiselitteisesti ei. Kohtaamattomuus, puutteellinen läsnäolo ja tarpeiden sivuuttaminen tuottavat kärsimystä, jonka lähde jää kiireessä helposti tunnistamatta.
Miten työelämään sitten voidaan lisätä sivistystä? Minna Mattila-Aalto palauttaa lukijan mieleen, että vanhalle kansalle sivistys oli arkista toimintaa. Samalla tavoin työelämän sivistys on puhtaasti ruumiillista, arkista työtä ja tekoa. Se ei ole jatkuvaa yksilöllistä edistymistä vaan jalostumista, joka vaatii pysähtymistä, asioiden yhteistä puntarointia ja - välillä - omista kannoista luopumista.

Tämän allekirjoitamme. Jäämmekin odottamaan kirjoittajalta seuraavaa kirjaa työelämäsivistyksestä kumpuavasta työelämän hyvinvoinnista.

Kirjaan kannattaa tarttua työelämän kehittäjien ja niiden, jotka haluavat laajentaa ymmärrystään sivistyksen merkityksestä.

\section{LAURI TUOMI}

KTT, toimitusjohtaja

Kvs-säätiö

MILLA HOLMBERG

KM, työnohjaaja, projektipäällikkö

Kvs-säätiö 